\title{
Developing a School Culture through Malamang Culture in Indonesia
}

\author{
Hariki Fitrah $^{1, *}$, Suyanto Suyanto ${ }^{1}$, Sugiharsono Sugiharsono ${ }^{1}$, Enung Hasanah ${ }^{2}$ \\ ${ }^{1}$ Education Science, Postgraduate Program, Yogyakarta State University, Indonesia \\ ${ }^{2}$ Educational Management, Faculty of Teachers Training and Education, Universitas Ahmad Dahlan, Indonesia
}

Received August 25, 2020; Revised October 29, 2020; Accepted November 11, 2020

\begin{abstract}
Cite This Paper in the following Citation Styles
(a): [1] Hariki Fitrah, Suyanto Suyanto, Sugiharsono Sugiharsono, Enung Hasanah, "Developing a School Culture through Malamang Culture in Indonesia," Universal Journal of Educational Research, Vol. 8, No. 12, pp. 6667 - 6675, 2020. DOI: 10.13189/ujer.2020.081231.
\end{abstract}

(b): Hariki Fitrah, Suyanto Suyanto, Sugiharsono Sugiharsono, Enung Hasanah (2020). Developing a School Culture through Malamang Culture in Indonesia. Universal Journal of Educational Research, 8(12), 6667 - 6675. DOI: 10.13189/ujer.2020.081231.

Copyright $\odot 2020$ by authors, all rights reserved. Authors agree that this article remains permanently open access under the terms of the Creative Commons Attribution License 4.0 International License

\begin{abstract}
Developing a school culture is an effort to create an effective school and produce quality school graduates, especially in terms of building student character. As a multicultural country, the development of school culture in Indonesia is more appropriate by developing a culture based on local culture. One of the cultures in Minangkabau, Indonesia is Malamang culture. This study aims to explore: (1) the process of developing school culture through Malamang Tradition at SMAN 1 Lubuk Alung, Indonesia; (2) the values contained in Malamang Tradition. The participants of this study were selected with a purposive sampling method, with the criteria that school members at SMA Lubuk Alung, Indonesia have experience in the process of developing school culture through Malamang tradition. The participants of this study consist of school principals, curriculum representatives, teacher councils, educational staff, students, and community leaders. This study used a qualitative method with an ethnographic approach. Data were collected through observation, interviews, and documentation. Data analysis is carried out through; (1) domain analysis, (2) taxonomic analysis, (3) component analysis, and (4) cultural theme analysis. The results show that: 1) the process of developing a school culture through Malamang tradition at SMAN 1 Lubuk Alung is carried out through a regional cultural festival which is held to commemorate the birthday of the great Prophet Muhammad SAW, routinely every year; 2) the values of Malamang tradition consist of cooperation value, mutual cooperation value, historical value, religious value, local culture love value, and
\end{abstract}

togetherness value.

Keywords School Culture, Character, Effective School, Malamang Tradition, Indonesia

\section{Introduction}

Indonesia is a multicultural country and one of the largest countries in the world that has more than 17,000 islands and has more than 730 languages and society cultures (Tumonggor, et al., 2013; Hasanah, et al., 2019). As a multicultural developing country, Indonesia meets a major problem in the education field, namely the unequal quality of education between regions (Idrus, 2012). While some schools can build good quality education (Demie \& Mclean, 2016), another problem faces low academic achievement or poor student behavior (Werang, 2018). In this problem, the Indonesian government has taken several policy steps to address the problem of inter-regional education in Indonesia.

The character development policy is one of the policies launched by the Indonesian Ministry of Education and Culture as an effort to solve education problems that occur in Indonesia (Nova, 2017). The Indonesian government and the various community leaders believe that character education can be the best solution in improving the quality of Indonesian people because character education is a process of building one's awareness through education 
which can build the quality of individual students and school communities (Pala, 2011). One of the ways to implement character education in schools is to instill local ethical and cultural values to all students (Kamaruddin, 2012; Agboola \& Tsai, 2012), in the form of developing school culture in the development of local culture-based culture (Meinarno, et al. , 2011; Pesurnay, 2018).

There are many ways to do character education in Indonesia (Riska, et al., 2019; Sulastri, 2020). The development of a school culture based on local culture is a process of developing understanding and application of behavior by a group of people in schools based on the values contained in the local culture in a certain area. Many schools have conducted this process in various regions in Indonesia because various research results show that the development of a school culture based on local culture has a positive impact on the character development of students (Lickona, 1991; Lickona, 2004; Lapsley \& Narvaez, 2006), resulting in educational output, quality (Madani, 2019), and the ability to increase school effectiveness (Duan, Du, $\& \mathrm{Yu}, 2018)$. The school culture gives the significant meaning to schools both internally and externally (Deal \& Peterson, 1990), because a positive school culture can encourage students, teachers, staff and principals to be more enthusiastic in achieving school goals, and can become a social glue (Zamroni, 2016). This notion is in line with several research results (Kisumo, et al., 2013; Maryamah, 2016; Zoma Pervez, Dahar, and Maryam, 2017) showing that the school culture can improve school quality and improve school performance.

The current problems are many schools have not been able to develop a school culture following the times' demands. Therefore, school culture development programs tend to fail and have not had an impact on school productivity, and have not been able to improve the education quality in schools. Based on the results of research conducted by Martinez (2014) shows that the low quality of education in schools that have tried to develop school culture is due to the lack of relevance between the developed culture and the school context and conditions. Based on the results of research conducted by Martinez, it can be seen that the school culture developed in an educational institution must be under school conditions, and according to social needs.

SMAN 1 Negeri Lubuk Alung, is a school located in the Indonesian Sumatra region which is known for its Malamang culture. This school is one of the schools in Indonesia that has succeeded in developing a local culture-based school culture through the development of Malamang tradition. They have succeeded in building student character and became well known as a school that produces smart graduates, who possess character and cultures. The Malamang tradition is a tradition that exists in the life of the Muslim society of Minangkabau, Sumatra, Indonesia, which is carried out annualy to commemorate the birthday of the Prophet Muhammad SAW. Aliman
(2017) says that cooking lamang or malamang in the Minangkabau language is a tradition of cooking pulut rice using bamboo as a container for cooking. Refisrul (2017) explains that the Malamang tradition is closely related to the history of the development of Islam in Minangkabau, Indonesia. At that time, the well-known scholar Sheikh Burhanuddin came to the Minangkabau coast to broadcast Islam, especially in the Ulakan area, Pariaman. According to Tambo, Sheikh Burhanuddin diligently comes to people's homes to stay in touch and broadcast the Islamic religion, and the house owners serve food to the guests when they are visiting. Even though Islam has started to develop, people do not know halal and haram. Therefore, he introduced to the public a way of cooking that could be guaranteed halal. Syekh Burhanuddin cooked rice in gutters (bamboo) which had not been touched by anyone. Therefore, it is called lamang rice and then becomes the malamang tradition. Zulfa and Kaksim (2014) prove that the malamang tradition has mutual cooperation values, the togetherness values, the responsibility values that are the character of the Minangkabau people themselves.

\section{Statement of Problems}

The need felt by school principals in Indonesia regarding how local culture-based school development practices in Indonesia are very high. Until now, there are very few references to the process of developing school culture, especially those based on the Malamang culture. In the other hand, SMA Negeri 1 Lubuk Alung is one of the schools that has successfully developed a school culture based on the Malamang culture. The success of SMA Negeri 1 Lubuk Alung in developing a school culture is a best practice, and it is important to study the process and its impact further. Therefore, this study has attempted to explore the process and results of the development of a school culture based on the Malamang culture in Indonesia, to fill the reference vacancy.

\section{Research Purposes}

This study aims to explore the process of developing a school culture through Malamang culture at SMAN 1 Negeri Lubuk Alung, Indonesia.

\section{Research Question}

The research questions of this study are (1) how the process of developing a school culture through Malamang Tradition at SMAN 1 Lubuk Alung is? (2) what values are there in the Malamang tradition?

\section{Research Methods}

This research is qualitative research with an ethnographic approach. According to Creswell (2015: 59), 
qualitative research is research that starts with assumptions and uses an interpretive or theoretical framework that shapes or influences the study of research problems related to the meaning imposed by individuals or groups in a social or human problem. Spradley (2007) also states that ethnography is a culture that studies other cultures which is a knowledge building, it includes research techniques, ethnographic theory, and various ethnographic descriptions; therefore ethnographic research is the best method for this research.

The step of this study is based on the steps suggested by Spradley (2007) namely, "Gradually Forward Research Flow". The research steps were carried out as follows (1) locating an informant, (2) interviewing an informant, (3) making an ethnographic record, (4) asking descriptive questions, (5) analyzing ethnographic interviews, (6) making a domain analysis, (7) asking structural questions, (8) making a taxonomic analysis, (9) asking contrast questions, (10) making a component analysis, (11) discovering cultural themes, (12) writing an ethnography.

\section{Participants}

Participants in this study are school members in SMAN 1 Lubuk Alung who are determined by purposive sampling According to Djamal (2015),to determine the participants by purposive sampling requires considerations and certain objectives.For example, people have a lot of information or the problem being studied, therefore to determine the criteria of the participants in this study,we looked for parties who are connected to SMAN Negeri 1 Negeri Lubuk Alung, Indonesia and have roles in the process of developing a school culture based on the Malamang culture. From these criteria, the participants in this study consist of principals, curriculum representatives, teacher councils, education staff, students, and society.

\section{Data Collection Process}

The data collection process in this study used three data collection methods, namely, observation, interviews, and documentation. The procedure is carried out as follows:

\section{a. Observation}

Observation activities are carried out to see the activities of school members such as extracurricular activities as well as the physical condition of the school or concerning educational supporting facilities and infrastructure such as classrooms, libraries, places of worship, and sports venues. To carry out this observation process, the participant directly activities at the school for several months.

\section{b. Interview}

The interview is conducted with school principals, deputy principals, teacher councils, education personnel, students, and the community through in-depth individual interviews. Each time the interview is conducted between 30-45 minutes for each participant at school.

\section{c. Documentation}

The documents as materials for data analysis are documents in the form of photos of activities or events carried out at school, school achievement data, school quality report cards, slogans, aphorisms, and mottos displayed in the school environment and school and student achievement trophies. From these documents, identifying various data is conducted with the process of developing a school culture that has been carried out.

\section{Data Analysis Technique}

This study uses ethnographic thematic analysis techniques which are carried out through three procedures: a. Researchers make a list of categories that stand out following the research objectives contained in the data collected from data (observations, interviews, documents, and audio and video recordings). The list of categories is a specific psychological or behavioral phenomenon of a particular cultural or ethnic group. b. Researchers give labels to the categories that appear. c. Based on the list of prominent categories, the researchers then made conclusions on the results of the research (Hanurawan, 2016).

\section{Data validity}

This study uses data triangulation to ensure the validity of the data, namely by retrieving data in various ways. Besides, this study carries out a member checklist to ensure that the data were taken and processed objectively and professionally. In addition, we also created a chronology of research implementation in the form of a research implementation journal, so that it is easier to track all the events that we have carried out in the research to validate the data presented.

\section{The Results}

Based on the data collected, several research results can be found in this study, which can be presented in the form of themes consist of the cultural process through the malamang culture, and values instilled through the Malamang culture.

\section{Theme 1. The process of developing a school culture through the malamang culture}

Based on the results of interviews with participants, it is 
known that the process of developing a school culture through the malamang culture begins with an assessment of the context of the local cultural environment. This is done by way of discussion and brainstorming between related parties, as stated by $\mathrm{P} 1$ as follows:

In connection with the formulation of school programs at SMAN 1 Lubuk Alung, we do it through a process of discussion and deliberation involving all school components, from which we will get the latest ideas and how they will be implemented (P1).

From the results of interviews and observations, it is known that SMA Negeri I Lubuk Alung has a tradition of collaboration and already understands the importance of collaborating with related parties who can support the success of the school, including in the process of developing school culture through the practice of the malamang culture carried out by all students. The relevant statement from P2 regarding this matter as follows.

... Involving all school components because the program is jointly created and run together; therefore, it must be in line with everything. The strategy carried out by schools in developing quality is by collaborating with various elements such as with the education office, local government, universities, alumni, and parents of students (P2).

When all school components have reached an understanding and common perception regarding the benefits of developing a school culture through the evening culture, the school will realize the program.

The results showed that the next step in the process of developing a school culture through the malamang tradition at SMA Negeri 1 Lubuk Alung is carried out in the form of organizing a regional cultural festival. The festival in question is an event in making lamang that involves all components of the school. Lamang is a food whose raw materials are made of glutinous rice, coconut milk, pandan leaves which are put into gutters (a type of bamboo) which are then burned using firewood. The process is carried out by the students, which each of them having different assignments.

In the process of implementing the Malamang tradition, the first thing that is done by the teachers is by giving explanations to the students about the process of the Malamang culture and what is the meaning of the Malamang culture. Then, teachers assign students to identify what each student could do in the evening process. The results of the self-identification were used by the teachers as material to determine the working group and determine what the tasks of each group were during the evening process. Even though each group already has their respective assignments, the teachers emphasize that one group and another group are encouraged to help each other so that the evening process can be completed at the same time.

In general, the process of working in the malamang tradition that is done by students can be seen in Figure 1 .

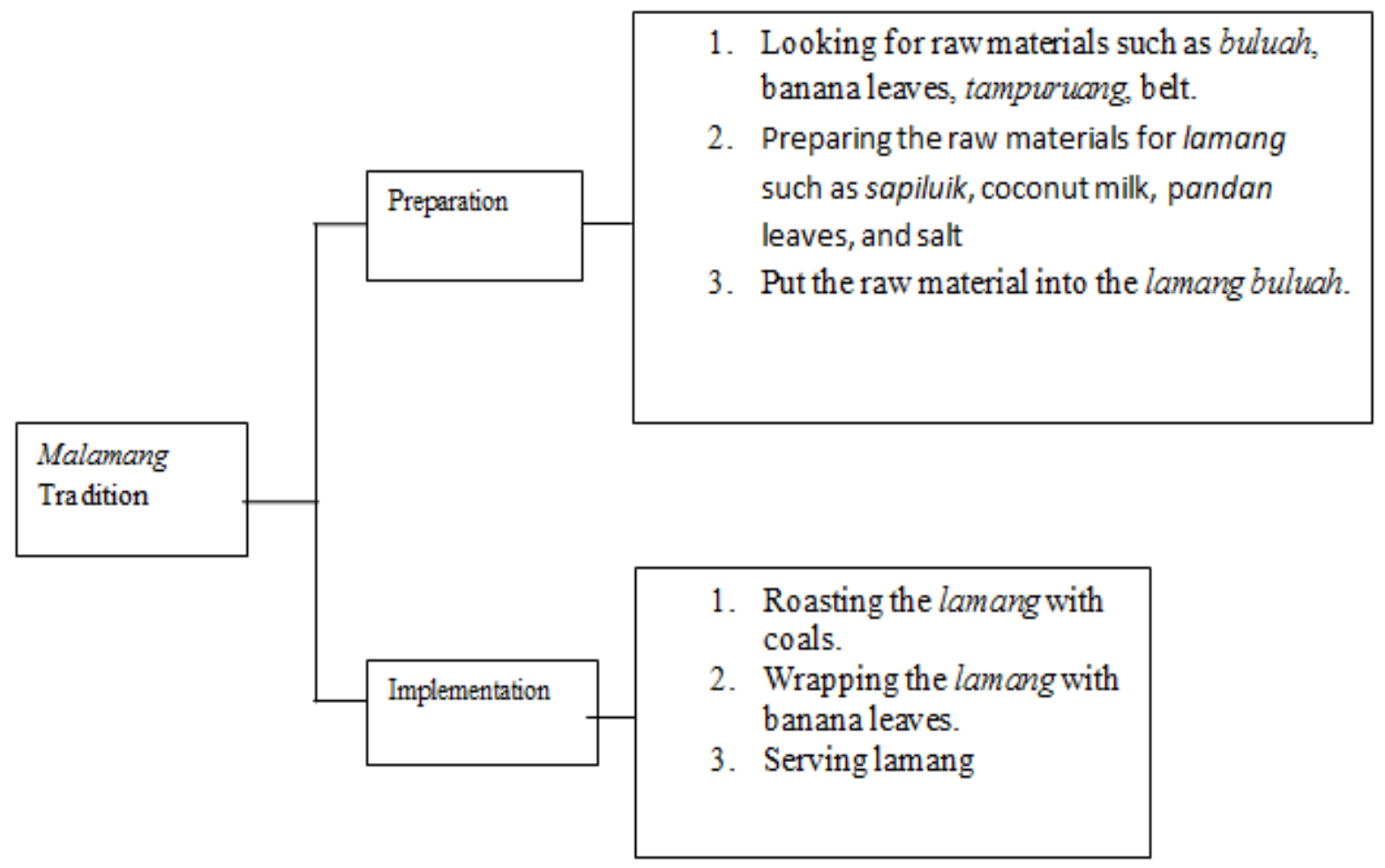

Figure 1. The process of making lamang in the malamang tradition 


\section{Theme 2. The values of malamang culture}

From the Malamang tradition, it can be seen that many life values can form a unified system in people's lives. Based on information from informants, the development of local culture in the school environment, forms character values in students. The character values that developed in the malamang tradition are the value of cooperation, mutual cooperation, historical values, religious values, love of regional culture, and togetherness. This idea is implied in the statement of one of the community leaders (P17) as follows:

Malamang culture is a tradition of cooking food made from glutinous rice which is mixed with coconut milk and put into bamboo and then baked. The meaning contained in this tradition is patience, mutual help, mutual cooperation according to the proverb of the Minang society 'Barek samo dipikua mild samo' (everything will be easier if done together). (P17)

Apart from the values of mutual cooperation and togetherness, Malamang consists of religious values, especially for Muslims. Malamang is always done by the Padang Pariaman society as a form of celebration and delight to commemorate the birthday of the Prophet Muhammad. This can be seen from the P3 statement as follows:
Malamang is a tradition of the Padang Pariaman people in making lamang food. Lamang is made of glutinous rice, coconut milk, salt and pandan leaves as a fragrance. Moreover, put it in a gutter trunk or a type of bamboo for baking. The malamang tradition is usually held at the Prophet Muhammad SAW's birthday event, and when someone dies, the philosophical meaning of the malamang event is the value of togetherness. This Malamang tradition has existed for a long time ago or since our ancestors. When viewed from a historical point of view, as well as stories from our parents that this night comes from the story or history of the story of Sheikh Burhanuddin who is a famous scholar in the Padang Pariaman area. When he spread Islam in Padang Pariaman, he entered the villages. At that time he was given food by the society and he doubted the halalness of the food. For that, he told the public to look for gutters or a type of bamboo for cooking lamang (P3).

Based on the various steps and forms of activities carried out during the malamang process, each of them has a meaning as part of character education for the students participating in the festival. From the whole process of the malamang cultural festival, which is carried out by all students, we can see the implication of malamang culture in developing students' characters in Table 1.

Table 1. The Values of the Malamang Tradition

\begin{tabular}{|c|c|c|c|c|c|}
\hline No & School Culture & $\begin{array}{l}\text { The Steps of } \\
\text { Activities }\end{array}$ & Activities & $\begin{array}{l}\text { Values are } \\
\text { produced }\end{array}$ & Description \\
\hline \multirow{6}{*}{1} & \multirow{6}{*}{$\begin{array}{l}\text { Malamang } \\
\text { Tradition }\end{array}$} & \multirow{3}{*}{ Preparation } & $\begin{array}{l}\text { Looking for raw materials such } \\
\text { as buluah, banana leaves, } \\
\text { tampuruang, and a belt. }\end{array}$ & Cooperation & $\begin{array}{l}\text { Attitudes that show mutual help, help } \\
\text { in completing a job. }\end{array}$ \\
\hline & & & $\begin{array}{c}\text { Preparing the raw materials for } \\
\text { lamang such as sapiluik, } \\
\text { coconut milk, pandan leaves, } \\
\text { and salt }\end{array}$ & $\begin{array}{l}\text { Mutual } \\
\text { cooperation }\end{array}$ & $\begin{array}{l}\text { Participate in an activity voluntarily } \\
\text { without expecting anything in return. }\end{array}$ \\
\hline & & & $\begin{array}{l}\text { Putting the lamang raw material } \\
\text { into the buluah }\end{array}$ & Togetherness & $\begin{array}{l}\text { An attitude that shows a sense of } \\
\text { kinship, intimacy, and brotherhood. }\end{array}$ \\
\hline & & Implementation & Roasting lamang with coals & History & $\begin{array}{l}\text { Values relating to the past that have } \\
\text { developed in people's lives to the } \\
\text { present. }\end{array}$ \\
\hline & & & $\begin{array}{c}\text { Wrapping the lamang in banana } \\
\text { leaves }\end{array}$ & $\begin{array}{l}\text { Resilient and } \\
\text { creative }\end{array}$ & $\begin{array}{l}\text { A person's skills at work and show } \\
\text { maximum results }\end{array}$ \\
\hline & & & Serving the lamang & Love culture & $\begin{array}{l}\text { An attitude that maintains and } \\
\text { preserves regional cultures that have } \\
\text { been passed down from generation to } \\
\text { generation }\end{array}$ \\
\hline
\end{tabular}

Source: Penggolahan data penelitian 2020 
Generally, the process of developing a school culture at SMA Negeri I Lubuk Alung has had a real impact in the form of the high quality and quality of education outcomes marked by society recognition of the high discipline attitudes of the students of SMA Negeri 1 Lubuk Alung. This can be seen from one of the following society admissions:

The superiority of SMAN 1 Lubuk Alung is high discipline, complete facilities, and infrastructure. Yes, they are often invited to various school activities such as guardianship meetings, committee meetings, taking children's report cards (P15).

This is supported by the statement of Participant 14 (P14) who is one of the parents of the student's guardian at SMA Negeri I Lubuk Alung as follows:

This school is the best school in Padang Pariaman and a favorite school for society because it is proven that many students are accepted into universities. There is society confidence in sending their children to SMAN 1 Lubuk Alung and having many achievements, complete school facilities. Besides, the school always interacts with the school in the learning development of our children, such as in taking report cards there are told of the weaknesses of students to be corrected. (P14).

\section{Discussion}

From the results of studies conducted at SMAN 1 Lubuk Alung, it can be seen that the development of a school culture through the Malamang tradition has a positive impact on the formation of student character and also makes a good contribution in preserving local culture. The Malamang tradition is not only limited to make lamang together but also has a strong meaning in people's lives. The research results conducted by Refisrul (2017) explain that the Malamang tradition is an expression of the Minangkabau society towards fulfilling the biological needs and social relationships of their fellowmen, both within the sphere of relatives and the wider society. From the research results conducted by Refisrul, it shows that the Malamang tradition can strengthen unity and integrity in social life. If it is related to school life, it will certainly create a harmonious school culture among school members.

School culture and local culture have a very important meaning in the development of an educational institution. Through school, the culture will provide strength for the school in dealing with or solving problems that occur. According to Peterson and Deal (2009: 11) say that positive school culture can increase school effectiveness and productivity. The opinion of Peterson and Deal shows that through the development of positive school cultures, it can improve the quality of schools. Meanwhile, research conducted by Angus J. et al. (2009) entitled "The Effects of School Culture and Climate on Student Achievement" states that the achievements achieved by students in schools are due to the healthy school learning environment. From the results of this study, it can be seen that school culture greatly determines student achievement. Schools that can build a healthy school culture always provide support and motivation to students to excel under the potential that exists in students. There is a strong relationship between school culture and student achievement, a positive school culture will have a good impact on improving student achievement and vice versa. This is also expressed by Zamroni (2016: 47) who says that the values contained in school culture will influence school members to view achievement and how attitudes and actions are for what achievement is.

Building a school culture needs to pay attention to the conditions and characteristics of a school such as location, socio-culture of the local society, geographical conditions, supporting facilities, and infrastructure. According to Willard Waller (1993) quoted by Peterson (2009: 8), it explains that schools have their own culture consisting of a set of rituals, habits, morals that are related to shaping the behavior of school members. From this opinion, it can be said that each school has its own school culture or each school has a different culture which is characteristic of an educational institution. Research on school culture was also conducted by Dwiningrum (2015: 186) explaining that every school has a cultural reality, where schools have different strategies in making school programs.

One of the regional cultures developed in the school culture at SMAN 1 Lubuk Alung is the malamang tradition. This tradition has become a distinctive feature for SMAN 1 Lubuk Alung because it is the only school in Padang Pariaman Regency that carries out regional traditions in the school program. According to Holstein and Gubrium in Denzin and Lincoln (2009: 343), local culture comes in various forms. Small groups, formal organizations, and other areas of everyday life condition what we face and how we perceive it. Meanwhile, Beals, Spindler, and Spindler (1973: 105) asserted that cultural tradition is a set of ideas and messages transmitted to each cultural system. The cultural system can survive if it meets two criteria, namely; (1) must be successful in convincing all members and serving them according to cultural traditions; (2) must be able to provide the necessary information and technology for adaptation to the environment.

The regional culture developed at school can be a capital for schools in developing character values in students. According to Dwiningrum (2018: 29) states that school culture as cultural capital will build habituation which is expected to shape student character. So it can be said that school culture is the capital for schools in building student character. The values that exist in local culture must be developed through traditions by involving all components of the school.

The formation of student character through the development of regional cultural values will be seen from 
the attitudes and actions of students in daily life, both at school, in the family environment, and in social life. Character is a moral attitude that exists in students which will affect the student's personality. According to Davidson, M., Lickona, T., and Khmelkov, V. in Nucci, LP, and Narvaez, D. (2008: 350) say that a smart and good school proposes eight character strengths as an important outcome of education, namely: (1) lifelong learner and critical thinker; (2) diligent and capable actors; (3) individuals with social and emotional skills; (4) ethical thinkers; (5) respectful and responsible moral agents; (6) individuals with self-discipline who pursue a healthy lifestyle; (7) participating community members and democratic citizens; and (8) a spiritual person who is involved in designing a life with a noble purpose. As for the meaning of the values that exist in the Malamang tradition, namely the value of cooperation, mutual cooperation, historical values, cultural values, religious values, and togetherness.

The cooperation value is a form of attitude that can work in a group to achieve the expected results. In the malamang tradition, students will be given the responsibility of preparing all the necessities or materials used in making lamang. In this activity, each student has their respective duties, such as someone who is tasked with preparing gutters (a type of bamboo) as a place or container that will be used as a place to cook lamang, some are in charge of providing raw materials such as glutinous rice and coconut milk. For the implementation of the event to run well, a committee in charge of the event is formed for each event. Therefore good cooperation will determine the success of the event.

The mutual cooperation value is a form of attitude that involves oneself in an activity voluntarily without expecting anything in return. According to Koentjaraningrat (1974: 63), mutual cooperation is the mobilization of labor without pay for a project that is beneficial to the public or that is useful for the government. In the malamang tradition, the spirit of mutual cooperation and sincerity in work is needed to get good results, this is very important because making lamang requires a lot of energy. In school lives, there are high spirit and spirit of mutual cooperation, heavy burdens will get lighter when done together. These values alsoexist in the Minangkabau people, namely, in the proverb barek samo dipikua, ringan samo dijinjiang, which means that when done together, it will be light.

Historical value is the value related to the past that affects people's lives and is closely held by society until now. According to its history, the Malamang tradition cannot be separated from the history of the spread of Islam in Padang Pariaman Regency. Through these historical values, students can interpret how Islam first entered the Padang Pariaman Regency.

The love culture value is an attitude that always maintains regional culture as an original culture which is manifested in the form of various activities related to cultural preservation such as arts, rituals, and traditions. Love culture is also a way of introducing local traditions to students. Through cultural love, it will motivate students to learn more about other cultural traditions so that traditions that have been passed down from generation to generation can exist among the younger generation.

Religious values are forms of attitudes and actions related to one's obedience to God Almighty. This can be seen from the behavior that carries out God's commands and avoids prohibitions. According to Uhi (2016: 95), the value of religiosity is essentially a driving force for humans to do good to others. Belief in God's power, accompanied by the belief that what God sends is also a source of goodness. This becomes a guide for human behavior in society, both as an individual and as a society. Religious values automatically become the basis for the emergence of other life values.

The togetherness value is a form of attitude that upholds a sense of brotherhood without discriminating between one another. In the malamang tradition at SMAN 1 Lubuk Alung, all school members are involved, and they unite in a family atmosphere. A sense of togetherness in school life will form closeness and intimacy between school members.

\section{Conclusions}

Based on the results of the discussion that has been described, it can be concluded that the Development of a School Culture through the Malamang Tradition at SMAN 1 Lubuk Alung is carried out through a regional cultural festival involving all school members. The Malamang tradition is carried out to commemorate the birthday of the great prophet Muhammad SAW. Through the Malamang tradition, many positive values can be developed in students, namely; (1) the cooperation value; (2) the mutual assistance value; (3) the historical value; (4) the love culture value; (5) the religious value; and (6) the togetherness value.

\section{Recommendation}

The results of this study indicate that process for developing school culture as one of the best ways to improve the quality of schools. Therefore, we recommend that school principals, especially in multicultural areas, be able to conduct 1) analysis of the local cultural environment suitable for development as a characteristic of the cultural properties of the school; 2) studies on local cultural values which are useful for improving the quality of schools; 3) practice local culture development in schools as an alternative model for implementing character education in schools. In the future, further research is needed regarding this process. 


\section{REFERENCES}

[1] Agboola, Alex \& Tsai, Kuan Chen. (2012). Bring Character Education into Classroom. European Journal of Educational Research. 3. 10.12973/eu-jer.1.2.163.

[2] Aliman, Muhammad. 2017. Local Wisdom of Minangkabau Tradition "Malamang" As a Supplementary Material In Teaching Geography At Senior High School. 2017 International Conference on Education and Science (ICONS 2017). https://www.researchgate.net/publication/321414014. Diakses 4 Maret 2020.

[3] Angus, J,. MacNeil,. Doris, L,. Prater \& Steve Busch. (2009). The Effects of School Culture and Climate on Student Achievement. International Journal of Leadership in Education. Vol.12, No. 1,. 73-84. DOI: $10.1080 / 13603120701576241$

[4] Beals, A,R,. Spindler, G,.\& Spindler, L,. (1973). Culture In Process. New York: Holt, Rinehart and Wintson, Inc.

[5] Creswell, J.W. 2015. Penelitian Kualitatif \& Desain Riset: Memilih di Antara Lima Pendekatan. (terjemahan Ahmad Lintang Lazuardi). Yogyakarta: Pustaka Pelajar. (edisi asli diterbitkan tahun 2013 by Sage, ISBN: 978-1-4129-9530-6)

[6] Deal, T, E,. \& Peterson, K,. D. (1999). Shaping School Culture: The Heart of Leadership. San Francisco: Jossey-Bass Publisher.

[7] Demie, Feyisa \& Mclean, Christabel. (2016). What Works in School Improvement: An example of good practice. 10.13140/RG.2.2.22460.64642.

[8] Denzin, N,. K. dan Lincoln, Y,.S. (2009). Handbook of Qualitative Research. (Terjemahan Dariyatno, Badrus Samsul Fata, Abi, John Rinaldi). Yogyakarta: Pustaka Pelajar. (Edisi asli pertama diterbitkan tahun 1997 dan edisi kedua tahun 2000 oleh Sage Publication)

[9] Djamal. (2015). Paradigma Penelitian Kualitatif. Edisi revisi. Mitra Pustaka: Yogyakarta.

[10] Duan, Xiaoju \& Du, Xiangyun \& Yu, Kai. (2018). School Culture and School Effectiveness: The Mediating Effect of Teachers' Job Satisfaction. International Journal of Learning, Teaching and Educational Research. 17. 15-25. 10.26803/ijlter.17.5.2.

[11] Dwiningrum, S, I,. A. 2015. Desentralisasi dan Partisipasi Masyarakat dalam Pendidikan. Yogyakarta: Pustaka Pelajar.

[12] Dwiningrum. S, I, A,. 2018. Culture-Based Education To Face Disruption Era. 3rd National Seminar on Educational Innovation (SNIP 2018). SHEs: Conference Series 1 (2) (2018) 20-38. https://Journal.uns.ac.id/shes. Diakses tanggal 5 April 2019.

[13] Hanurawan, Fattah. 2016. Metode Penelitian Kualitatif Untuk Ilmu Psikologi. Jakarta: RajaGrafindo Persada

[14] Hasanah, E., Zamroni, Z., Dardiri, A., \& Supardi, S. (2019). Indonesian Adolescents Experience of Parenting Processes that Positively Impacted Youth Identity. The Qualitative Report, 24(3), 499-512. Retrieved from https://nsuworks.nova.edu/tqr/vol24/iss3/5

[15] Idrus, Muhammad. (2012). Mutu pendidikan dan pemerataan pendidikan di daerah. Psikopedagogia Jurnal
Bimbingan dan Konseling. 1. 10.12928/psikopedagogia.v1i 2.4603 .

[16] Kamaruddin, Syamsu. (2012). Character Education and Students Social Behavior. Journal of Education and Learning (EduLearn). 6. 223. 10.11591/edulearn.v6i4.166.

[17] Kisumo, C, C,. Osman, A,. Ongeti, K,. (2013). School Culture: Implications to School Improvement and Performance in National Examinations in Kenya. JETERAPS. 4 (1): 94-99. ISSN: 2141-6990.

[18] Koentjaraningrat. (1974). Kebudayaan, Mentalitet dan Pembangunan. Jakarta: Gramedia

[19] Lapsley, D. K., \& Narvaez, D. (2006). Character Education. In K. A. Renninger, I. E. Sigel, W. Damon, \& R. M. Lerner (Eds.), Handbook of child psychology: Child psychology in practice (p. 248-296). John Wiley \& Sons Inc.

[20] Lickona, Thomas (2004), Character matters: How to help our children develop good judgment, integrity, and other essential virtues. New York: Touchstone.

[21] Lickona, T. (1991). Educating For Character: How Our School Can Teach Respect and Rresponsibility. New York: Bantam Books.

[22] Madani, Rehaf. (2019). Analysis of Educational Quality, a Goal of Education for All Policy. Higher Education Studies. 9. 100. 10.5539/hes.v9n1p100.

[23] Martinez, Donna. (2014). School Culture and American Indian Educational Outcomes. Procedia Social and Behavioral Sciences. 116 (2014) 199-205. DOI: 10.106/j.sbspro.2014.01.194.

[24] Maryamah, Eva. (2016). Pengembangan Budaya Sekolah. Jurnal Tarbawi. Volume 2, No.2. 86-96. Juli-Desember 2016. ISSN: 2442-8809.

[25] Meinarno, E, A,. Widianto, B,. Halida, R,. (2011). Manusia dalam Kebudayaan dan Masyarakat: Pandangan Antropologi dan Sosiologi Edisi 2. Jakarta: Salemba Humanika.

[26] Nova, Muhamad. (2017). Character Education in Indonesian EFL Classroom: Implementation and Obstacles. Jurnal Pendidikan Karakter. 7. 10.21831/jpk.v7i2.13650.

[27] Nucci, L.P,.dan Narvaez, D. (2008). Handbook Pendidikan Moral dan Karakter. (Terjemahan Imam Baehaqie dan Derta Sri Widowatie). Bandung: Nusa Media. (Edisi asli diterbitkan tahun 2008. New York: Routledge).

[28] Pala, Aynur. (2011). THE NEED FOR CHARACTER EDUCATION. International Journal of Social Sciences and Humanity Studies. 3.

[29] Pesurnay, Althien. (2018). Local Wisdom in a New Paradigm: Applying System Theory to the Study of Local Culture in Indonesia. IOP Conference Series: Earth and Environmental Science. 175. 012037. 10.1088/1755-1315/1 75/1/012037.

[30] Peterson, K. D. Deal, T.E. (2009). Shaping School Culture field book. Second Edition. San Francisco: Jossey-Bass.

[31] Peterson, K.D. dan Deal, T.E. (1999). Shaping School Culture: The Heart of leadership. San Francisco: Jossey-Bass. 
[32] Riska Anggraini Saputri, Muchtarom , Triyanto, Winarno (2019). Reinforcing Civics Literacy in Sustaining Students' Learning in the Industrial Era 4.0. Universal Journal of Educational Research, 7(9A), 36 - 43. DOI: 10.13189/ujer.2019.071605.

[33] Refisrul. 2017. Lamang dan Tradisi Malamang pada Masyarakat Minangkabau. Jurnal Penelitian Sejarah dan Budaya. Volume 3 No.2. November 2017. Hal 772-796. http://jurnalbpnbsumbar.kemendikbud.go.id. Diakses tanggal 12 November 2019..

[34] Sulastri Rini Rindrayani (2020). The Implementation of Character Education in Indonesia High School Curriculum Program. Universal Journal of Educational Research, 8(1), 304 - 312. DOI: 10.13189/ujer.2020.080137

[35] Spradley, J.P,. 2007. Metode etnografi. (Terjemahan Misbah Zulfa Elizabeth). Yogyakarta: Tiara Wacana. (edisi asli diterbitkan tahun 1979 oleh Wadsworth Publishing Company, Belmont, California).

[36] Tumonggor, Meryanne \& Karafet, Tatiana \& Hallmark, Brian \& Lansing, John \& Sudoyo, Herawati \& Hammer, Michael \& Cox, Murray. (2013). The Indonesian archipelago: An ancient genetic highway linking Asia and the Pacific. Journal of human genetics. 58. 10.1038/jhg.2012.154.

[37] Uhi, J, A,. (2016). Filsafat Kebudayaan: Konstruksi Pemikiran Cornelis Anthonie van Peursen dan Catatan Reflektifnya. Yogyakarta: Pustaka Pelajar.

[38] Werang, Basilius. (2018). Investigating Students' Learning Motivation in Indonesian Higher Institution: A Study form Musamus University of Merauke, Papua. 7.

[39] Zamroni. 2016. Kultur Sekolah. Yogyakarta: Gavin Kalam Utama

[40] Zoma Pervez, Z, Dahar, M.A. and Maryam, A. (2017). Impact of school culture on student's academic achievement at secondary level. Sci.Int.(Lahore), 29(3),565-568,2017 ISSN: 1013-5316; CODEN: SINTE 8

[41] Zulfa dan Kaksim. (2014). Sistem Pola Pewarisan Tradisi Malamang di KoTA Padang. Jurnal Kajian Budaya. Volume. 10 No.20. Juli 2014. Hal 57-72. https://ojs.unud.ac.id/index.php/kajian/article/view/13872/9 579. 